\title{
Proton Transport in Catalyst Layers of a Polymer Electrolyte Water Electrolyzer: Effect of the Anode Catalyst Loading
}

\author{
Ugljesa Babic, ${ }^{1}$ Elisabeth Nilsson, ${ }^{1}$ Alexandra Pătru, ${ }^{1}{ }^{1}$ Thomas J. Schmidt, ${ }^{1,2, *}$ \\ and Lorenz Gubler $\circledast^{1, *, z}$
}

${ }^{I}$ Electrochemistry Laboratory, Paul Scherrer Institut, 5232 Villigen PSI, Switzerland

${ }^{2}$ Laboratory of Physical Chemistry, ETH Zürich, 8093 Zürich, Switzerland

\begin{abstract}
The understanding of loss terms in polymer electrolyte water electrolysis (PEWE) cells is essential to maximize efficiency and minimize cost and enable the technology for energy applications, such as "power-to-X". We adapt the use of the transmission-line model for porous electrodes in conjunction with electrochemical impedance spectroscopy measurements of the cell in the $\mathrm{H}_{2} / \mathrm{N}_{2}$ mode known for fuel cells to PEWE cells to quantify proton transport resistance and double layer capacitance of the anode catalyst layer. Anode catalyst loading was varied between 0.05 and $3.2 \mathrm{mg}_{\mathrm{IrO} 2} \mathrm{~cm}^{-2}$. A non-linear relationship was found between the anode $\mathrm{IrO}_{2}$ loading and the proton transport resistance. Catalyst layers with very low $\mathrm{IrO}_{2}$ loading $\left(0.05-0.16 \mathrm{mg}_{\mathrm{IrO}} \mathrm{cm}^{-2}\right)$ had $\sim 4$ times higher mass-specific activity and $\sim 2$ times higher mass-specific capacitance, revealing an inhomogeneous utilization of the catalytic material. The kinetic and transport limitations associated with the anode catalyst layer have been correlated with its morphological features.

(C) The Author(s) 2019. Published by ECS. This is an open access article distributed under the terms of the Creative Commons Attribution 4.0 License (CC BY, http://creativecommons.org/licenses/by/4.0/), which permits unrestricted reuse of the work in any medium, provided the original work is properly cited. [DOI: 10.1149/2.0341904jes]

(cc) BY
\end{abstract}

Manuscript submitted September 4, 2018; revised manuscript received January 24, 2019. Published February 22, 2019.

The dynamic capabilities and wide current density operation range of polymer electrolyte water electrolysis (PEWE) make it attractive for converting renewable electricity from the grid to $\mathrm{H}_{2}$ in the context of "power-to-X" ${ }^{1-6} \mathrm{PEWE}$ is especially attractive in power grids with a high share of fluctuating renewables, where the $\mathrm{H}_{2}$ can be used for seasonal energy storage. $\mathrm{H}_{2}$ as an energy vector is versatile since it can be re-electrified in a fuel cell for grid balancing, used in the mobility sector in fuel cell electric vehicles, or utilized in chemical industries to promote deep decarbonization of the energy sector. ${ }^{1,5}$ Furthermore, produced $\mathrm{H}_{2}$ can be used in a downstream methanation process to form synthetic natural gas ( $\mathrm{SNG}$ ) using suitable, preferably renewable $\mathrm{CO}_{2}$ and to feed it into the existing gas grid. ${ }^{6}$ Moreover, mixtures of $\mathrm{H}_{2}$ and $\mathrm{CO}_{2}$ can be used to produce syngas and subsequently liquid hydrocarbon energy carriers via a gas-to-liquid process.

The PEWE technology is currently plagued by issues associated with cost and component durability. ${ }^{7,8}$ The oxygen evolution reaction (OER) in acidic medium on the anode is currently catalyzed by precious materials from the platinum group metals (PGM). However, the cost of the catalyst materials has been estimated to contribute only $8 \%$ to the cost of the commercial stack. ${ }^{9}$ The final cost of the produced $\mathrm{H}_{2}$ is not greatly affected by the cost contribution of the stack components. ${ }^{10}$ It is dominated by the cost of electricity (currently $\sim 70 \%$ of the hydrogen end cost), and is therefore heavily dependent on the voltage efficiency of the stack. ${ }^{10}$ The type of the OER catalyst and its loading on the other hand have a large impact the stack voltage efficiency through the activation overpotential $\left(\eta_{\text {act }}\right) .{ }^{11,12}$

Iridium oxide $\left(\mathrm{IrO}_{2}\right)$ is the state-of-the-art PGM to catalyze the OER in commercial PEWE stacks. ${ }^{7,8}$ The most active material toward the OER is ruthenium oxide, but the dissolution rates remain too high for commercial implementation in the aggressive PEWE anode environment, in spite of extensive efforts to stabilize it. ${ }^{13}$ Higher loadings are preferred to maintain high stack voltage efficiency and reduce the end cost of $\mathrm{H}_{2}$. Maintaining a high $\mathrm{IrO}_{2}$ loading in the anode catalyst layer $\left(\mathrm{CL}_{\mathrm{a}}\right)$ at high market penetration of PEWE in the energy sector might not be viable due to the low abundance and limited supply of iridium, especially considering it is a by-product of the $\mathrm{Cu}, \mathrm{Ni}$ and $\mathrm{Pt}$ mining. ${ }^{14}$ The state-of-the art PEWE stacks $\left(\sim 4 \mathrm{~W} \mathrm{~cm}^{-2}\right.$ and $2 \mathrm{mg}_{\mathrm{IrO} 2}$ $\mathrm{cm}^{-2}$ ) would require around $500 \mathrm{~kg}_{\mathrm{IrO} 2} / \mathrm{GW}$. This would allow for an annual rate of capacity increase of $2 \mathrm{GW} / \mathrm{a}$, considering the annual production rate of iridium of 4 tons per annum and assuming a use of $25 \%$ of this for PEWE. ${ }^{8}$ Reduction of the $\mathrm{IrO}_{2}$ loading using

\footnotetext{
*Electrochemical Society Member.
}

${ }^{\mathrm{z}}$ E-mail: lorenz.gubler@psi.ch supported, ${ }^{15-17}$ high surface area catalysts ${ }^{18-20}$ or a nanostructured thin film catalyst ${ }^{21}$ is necessary to enable higher penetration of PEWE. On the other hand, reduction of the $\mathrm{IrO}_{2}$ loading is only justifiable while maintaining high voltage efficiency of the PEWE stack.

Understanding the factors that determine the catalyst utilization is necessary to direct the development of the next-generation catalyst layers for the electrochemical water splitting technology. A set of diagnostic tools is required to benchmark catalyst layer performance and make correlations between the morphology and the overpotential in the polarization characteristics of a PEWE cell. In this study we present a detailed methodology for obtaining the proton transport resistance $\left(R_{\mathrm{CLa}}^{\mathrm{H}+}\right)$ and the double layer capacitance of the $\mathrm{CL}_{\mathrm{a}}$ from electrochemical impedance spectra collected in the $\mathrm{H}_{2} / \mathrm{N}_{2}$ regime. The approach has been widely used in polymer electrolyte fuel cell (PEFC) technology 22 and is adapted here for a PEWE cell. The impedance is analyzed using the transmission-line model (TLM) $)^{22-26}$ to establish a correlation between the physical characteristics of the $\mathrm{CL}_{\mathrm{a}}$ and the transport properties. The method is then tested on catalyst layers with loading varied between 0.05 and $3.2 \mathrm{mg}_{\mathrm{IrO} 2} \mathrm{~cm}^{-2}$. The analysis is accompanied by cell voltage breakdown analysis based on the Tafel model previously reported in PEWE and PEFC literature. ${ }^{27-31}$

\section{Experimental}

Cell and test-station.- - A test bench developed in-house, equipped with a SP-150 potentiostat and a VMP3B 80A booster from Biologic was used to perform experiments. MiliQ water was circulated at a flow rate of $400 \mathrm{~mL} \mathrm{~min}^{-1}$ from a heated gas-water separator through the anode PEWE cell compartment. A PEWE cell with an active area of $25 \mathrm{~cm}^{2}$ with parallel flow fields was used to accommodate commercial T10 sintered-Ti porous transport layers (PTLs) from GKN. The electro-osmotically dragged water was discarded periodically from the cathodic gas-water separator. Cell housing, inlet and outlet temperatures were monitored during the experiments, and the average temperature was used to specify the operating temperature.

CCM preparation.-In-house prepared CCMs were based on the Nafion 117 (DuPont) perfluorosulfonic acid membrane. Nafion 117 sheets of $10 \times 10 \mathrm{~cm}$ were immersed in a $\sim 30 \mathrm{vol} \% \mathrm{HNO}_{3}$ (VWR Chemicals) solution at $80^{\circ} \mathrm{C}$ for $1 \mathrm{~h}$ to protonate the sulfonic acid groups and remove impurities. Boiling steps were repeated 4 times in MiliQ water to remove the acid from the membrane. Membranes were dried for $12 \mathrm{~h}$ before weighing, and afterwards mounted into a PEEK-based frame for spraying. 
Table I. Properties of the $\mathrm{IrO}_{2} / \mathrm{TiO}_{2}$ based catalyst layers for PEWE. The catalyst layer thickness $\left(d_{\mathrm{CLa}}\right)$ is obtained from the CCM cross-sections observed with SEM. The anode catalyst layer proton transport resistance $\left(R_{\mathrm{CLa}}^{\mathrm{H}+}\right)$ and the double layer capacitance $\left(C_{\mathrm{DL}}\right)$ values are extracted from the cell impedance measured in the $\mathrm{H}_{2} / \mathrm{N}_{2}$ regime at $60^{\circ} \mathrm{C}$. Proton resistivity of the anode catalyst layer $\left(\rho_{\mathrm{CLa}}^{H^{+}}\right)$was calculated from $R_{\mathrm{CLa}}^{\mathrm{H}+}$ and $d_{\mathrm{CLa}}$ values. The tortuosity $(\tau)$ of the electrode was calculated using Equation 5 . The Tafel slope $(b)$ and the anode catalyst activity $\left(i_{\mathrm{a}}\right)$ are extrapolated from the $i R$-free polarization curves at $60^{\circ} \mathrm{C}$. The mass specific quantities $c_{\mathrm{DL}}^{\mathrm{m}}$ and $i_{\mathrm{a}}^{\mathrm{m}}$ are obtained by normalizing the calculated values to the $\mathrm{IrO} \mathrm{O}_{2}$ loading.

\begin{tabular}{|c|c|c|c|c|c|c|c|c|c|}
\hline Loading $\left(\mathrm{mg}_{\mathrm{IrO} 2} \mathrm{~cm}^{-2}\right)$ & $d_{\mathrm{CLa}}(\mu \mathrm{m})$ & $R_{\mathrm{CLa}}^{\mathrm{H}+*}\left(\mathrm{~m} \Omega \mathrm{cm}^{2}\right)$ & $C_{\mathrm{DL}} *(\mathrm{~F})$ & $c_{\mathrm{DL}}^{\mathrm{m}} *\left(\mathrm{~F} \mathrm{~g}^{-1}\right)$ & $i_{\mathrm{a}}^{* *}(\mathrm{~A})$ & $i_{\mathrm{a}}^{\mathrm{m} * *}\left(\mathrm{~A} \mathrm{~g}^{-1}\right)$ & $b(\mathrm{mV} / \mathrm{dec})$ & $\rho_{\mathrm{CLa}}^{H^{+}} *(\Omega \mathrm{cm})$ & $\tau^{*}$ \\
\hline 0.05 & $1.0 \pm 0.2$ & 38.9 & 0.1 & 119 & 0.07 & 55 & $70 \pm 2$ & $1062 \pm 12$ & $23.7 \pm 0.6$ \\
\hline 0.16 & $1.1 \pm 0.1$ & 6.2 & 0.5 & 115 & 0.14 & 46 & $57 \pm 1$ & $164 \pm 4$ & $4.6 \pm 0.7$ \\
\hline 0.8 & $2.6 \pm 0.8$ & 10.3 & 1.1 & 54 & 0.27 & 16 & $54 \pm 1$ & $120 \pm 8$ & $3.4 \pm 0.6$ \\
\hline 1.2 & $3.5 \pm 0.6$ & 4.4 & 1.4 & 45 & 0.33 & 12 & $54 \pm 2$ & $38 \pm 7$ & $1.1 \pm 0.7$ \\
\hline 1.8 & $4.3 \pm 0.5$ & 25.6 & 1.8 & 40 & 0.65 & 15 & $55 \pm 1$ & $179 \pm 6$ & $5.1 \pm 0.5$ \\
\hline 2.6 & $5.8 \pm 0.3$ & 27.6 & 3.9 & 60 & 0.85 & 15 & $56 \pm 1$ & $144 \pm 6$ & $4.1 \pm 0.6$ \\
\hline 3.2 & $8.3 \pm 0.4$ & 35.7 & 4.4 & 55 & 1.32 & 20 & $55 \pm 1$ & $129 \pm 5$ & $3.7 \pm 0.8$ \\
\hline
\end{tabular}

Uncertainties for the other calculated values are provided in Figures 4, 5, 8 .

${ }^{*}$ Calculated from the EIS in the $\mathrm{H}_{2} / \mathrm{N}_{2}$ regime.

** Calculated from the iR-free polarization curve at $1.47 \mathrm{~V}$.

The anode catalyst ink was prepared by mixing $0.85 \mathrm{~mL}$ isopropanol, $2.7 \mathrm{~mL}$ miliQ water and $2.54 \mathrm{~mL}$ Nafion Solution (Aldrich, $5 \mathrm{w} \%$ Nafion). The ink was sonicated for 15 minutes. $1 \mathrm{~g}$ of $\mathrm{IrTiO}_{2}$ catalyst (Umicore, $66 \mathrm{~mol} \% \mathrm{IrO}_{2}$ and $34 \mathrm{~mol}^{2} \mathrm{TiO}_{2}$ ) was added to the solution and sonicated for additional $30 \mathrm{~min}$. The ink was sprayed onto the membrane using an airbrush pencil (Conrad Electronics Airbrush Pistol HP-200). The CCMs were dried again for $12 \mathrm{~h}$ and subsequently weighed. The ink-spraying preparation method yielded anode loadings from 0.05 to $3.2 \mathrm{mg}_{\mathrm{IrO} 2} \mathrm{~cm}^{-2}$. A gas diffusion electrode (Johnson Matthey ELE-0244-0542 with HiSpec $9100 \mathrm{Pt} / \mathrm{C} 0.4 \mathrm{mg}_{\mathrm{P}_{\mathrm{t}}} / \mathrm{cm}^{2}$ ) was used as the cathode. The CCMs were assembled in the wet state after immersion in miliQ water for $12 \mathrm{~h}$ before testing.

Experimental conditions.-Cells were conditioned at $60^{\circ} \mathrm{C}$ by cycling the current density between 1 and $2 \mathrm{~A} \mathrm{~cm}^{-2}$ until stable performance and uniform temperatures in the system were achieved. Polarization curves were recorded galvanostatically, while measuring the cell impedance at $10 \mathrm{kHz}$ at every current step. The measurements were repeated at 50,60 and $70^{\circ} \mathrm{C}$. PEWE cells were operated in the $\mathrm{H}_{2} / \mathrm{N}_{2}$ regime to measure the ionic resistance of the anode catalyst

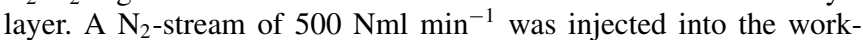
ing electrode (WE) water loop, while the reference/counter electrode (RE/CE) was supplied with humidified $\mathrm{H}_{2}$ at $400 \mathrm{Nml} \mathrm{min}^{-1}$. We ensured no faradaic current was measured before recording the electrochemical impedance spectrum (EIS). The impedance in $\mathrm{H}_{2} / \mathrm{N}_{2}$ mode was recorded from $10 \mathrm{kHz}$ to $300 \mathrm{mHz}$ potentiostatically at $1.0,1.2$ and $1.4 \mathrm{~V}$. No faradaic current was observed at these potentials during the collection of the impedance spectra. Cyclic voltammograms (CVs) were measured in the potential range between 0 and $1.4 \mathrm{~V}$ vs. RHE at a sweep rate of $50 \mathrm{mV} / \mathrm{s}$.

\section{Results and Discussion}

Morphological analysis.—Post-test CCM samples were cryogenically fractured in liquid nitrogen and analyzed using a Zeiss Supra VP55 scanning electron microscope, with an acceleration voltage of 5 $\mathrm{kV}$. CCM cross-sections were previously sputter-coated with a $\sim 7 \mathrm{~nm}$ Cr-layer for better electrical conductivity. CCM cross-sections were investigated using the scanning electron microscope (SEM) to determine the thickness of the $\mathrm{CL}_{\mathrm{a}}$ with different loadings (Table I), which was found to increase with $2.15 \pm 0.13 \mu \mathrm{m} \mathrm{mg}_{\mathrm{IrO} 2}{ }^{-1} \mathrm{~cm}^{2}$. An airbrush sprayed $\mathrm{CL}_{\mathrm{a}}$ consists of catalytic agglomerates $100-400 \mathrm{~nm}$ in size, connected by an ionomer film (Figure 1). The structure contains pores (voids) with a wide size distribution (0.1-1.5 $\mu \mathrm{m}$ in diameter). The cross-section of the $0.05 \mathrm{mg}_{\mathrm{IrO} 2} \mathrm{~cm}^{-2}$ anode shows only a few catalytic agglomerates. The anode surface images reveal how the catalytic agglomerates are interconnected laterally. Lower loaded anodes are less homogeneous in-plane, and the ionic network is more frequently dis- rupted. The $\mathrm{CL}_{\mathrm{a}}$ of the $0.05 \mathrm{mg}_{\mathrm{IrO} 2} \mathrm{~cm}^{-2}$ anode is very thin, and the agglomerates are often disconnected. The surface catalytic agglomerates of the thick $\mathrm{CL}_{\mathrm{a}}$ are ionically well interconnected through the ionomer covering the agglomerates underneath.

Transmission line model for porous electrodes.-The AC impedance response of the $\mathrm{CL}_{\mathrm{a}}$ is analyzed using the one-dimensional transmission-line model (TLM), typically used for the characterization of porous electrodes in electrochemical applications, including PEFC CLs. ${ }^{22-26}$ According to the TLM, the CL consists of differential elements describing the proton transport resistance, double layer capacitance $\left(C_{\mathrm{DL}}\right)$ and charge transfer resistance $\left(R_{\mathrm{CT}}\right)$ (Figure 2$)$. The TLM is often simplified by using an inert gas fed working electrode (WE), and $\mathrm{H}_{2}$-fed reference/counter electrode (RE/CE). When the potential is applied, the permeating $\mathrm{H}_{2}$ from the $\mathrm{RE} / \mathrm{CE}$ cell compartment is the reactant for the permeation-rate limited hydrogen oxidation reaction (HOR) on the WE. The measured DC current corresponds to the hydrogen crossover current, which varies with the membrane thickness,
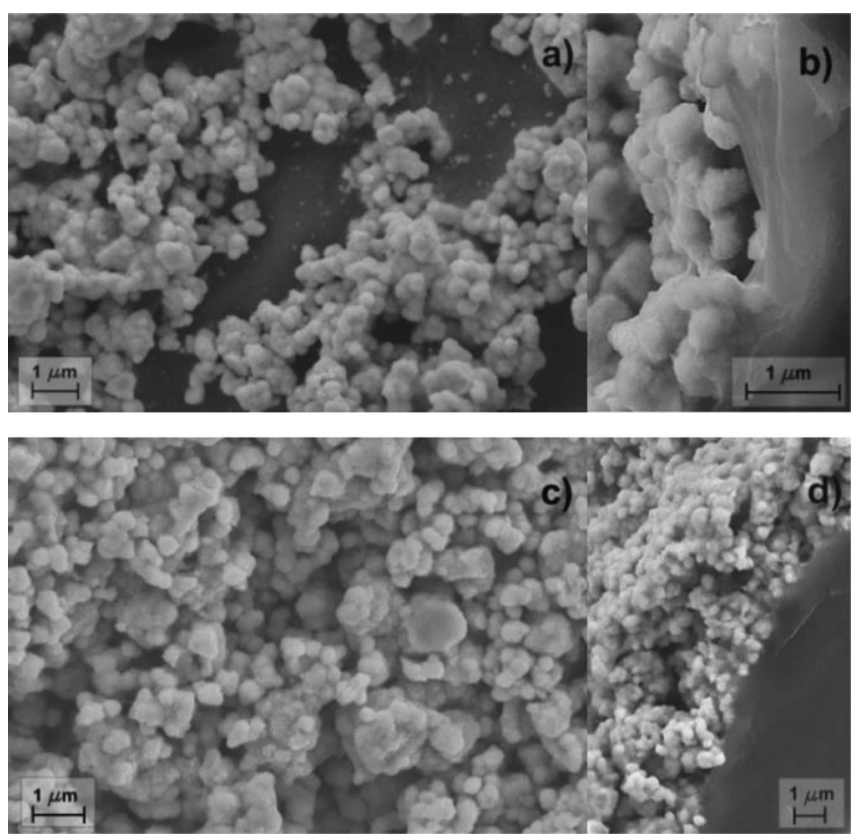

Figure 1. Surface of the anode catalyst layers with a loading of a) $0.05 \mathrm{mg}_{\mathrm{IrO} 2}$ $\mathrm{cm}^{-2}$ and c) $1.2 \mathrm{mg}_{\mathrm{IrO} 2} \mathrm{~cm}^{-2}$ and their respective cross-sections b) and d), observed under the scanning electron microscope. 


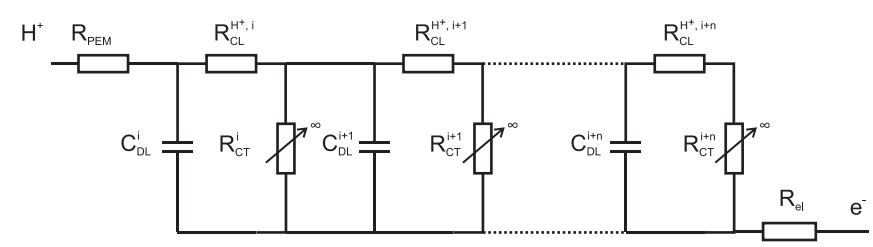

Figure 2. Equivalent circuit of the transmission line model for porous electrodes, consisting of differential elements describing the proton transport resistance in the catalyst layer $R_{\mathrm{CLa}}^{\mathrm{H}+}$, double layer capacitance $C_{\mathrm{DL}}$ and the kinetic resistance related to the electrochemical reaction $R_{\mathrm{CT}}$. In the $\mathrm{H}_{2} / \mathrm{N}_{2}$ regime, the impact of the kinetic resistances becomes negligible $\left(R_{\mathrm{CT}} \rightarrow \infty\right)$ due to the near-absence of the faradaic reaction on the electrode.

temperature, pressure and relative humidity conditions in the cell. The crossover current does not contribute to the total impedance, and the low charge-transfer resistance of the HOR and the HER reactions allows for the simplification of the $\mathrm{CL}_{\mathrm{a}}$ equivalent circuit (Figure 2). The electrode-electrolyte interface in this case behaves as a simple capacitor, which simplifies the analysis of the impedance spectra, as the charge-transfer arc following the high-frequency $45^{\circ}$ region toward low frequencies vanishes (Figure 3 ). ${ }^{22,23}$ Deviation from the capacitive behavior at low frequency could result from structural inhomogeneity of the electrode. ${ }^{32}$ Impedance spectra are recorded at 1.0, 1.2 and $1.4 \mathrm{~V}$ representing a potential region beyond the OER regime. ${ }^{33}$

The absence of a faradaic reaction on the WE greatly simplifies the impedance analysis and the estimation of the TLM equivalent circuit elements describing $R_{\mathrm{CLa}}^{\mathrm{H}+}$ and $C_{\mathrm{DL}}$. The equation describing the impedance response of the $\mathrm{CL}^{22}$ can therefore be simplified according to

$$
Z(f)=H F R+\sqrt{\frac{R_{\mathrm{CLa}}^{\mathrm{H}+}}{2 \pi f C_{\mathrm{DL}} j}} \operatorname{coth}\left(\sqrt{2 \pi f C_{\mathrm{DL}} j R_{\mathrm{CLa}}^{\mathrm{H}+}}\right)
$$

where $j$ is the imaginary unit (the symbol ' $i$ ' is used for current density). In the special case when the frequency $(f)$ tends to zero, the WE impedance becomes

$$
\lim _{f \rightarrow 0} Z(f)=\lim _{f \rightarrow 0}[\operatorname{Re}(Z)+j \operatorname{Im}(Z)] \approx \frac{R_{\mathrm{CLa}}^{\mathrm{H}+}}{3}-\frac{j}{2 \pi f C_{\mathrm{DL}}}
$$

The $C_{\mathrm{DL}}$ can be obtained from the limiting impedance at low $f .{ }^{22}$ Instead of assuming constant $\operatorname{Im}(Z)$ and averaging it at low $f,{ }^{24}$ we have estimated the $C_{\mathrm{DL}}$ according to Equation 3 using $\operatorname{Im}(\mathrm{Z})$ at the minimum phase angle $\left(\varphi_{\min }\right)$, when the transition to the capacitive behavior sets in. The $\varphi_{\min }$ is obtain at lower frequencies for thicker $\mathrm{CL}_{\mathrm{a}}$, as the $\mathrm{AC}$ current needs to penetrate longer pores. When the pores are penetrated, the $\varphi$ goes through a minimum value and increases asymptotically to $90^{\circ}$. The uncertainty of averaging is in this way mitigated, since the $\operatorname{Im}(Z)$ in Equation 2 often does not exhibit a plateau at low $f$, especially with low catalyst loadings. ${ }^{34}$ Another way to calculate $C_{\mathrm{DL}}$ is by dividing the average $\mathrm{CV}$ current in the potential range of $1.0-1.4 \mathrm{~V}$ by the sweep rate. $C_{\mathrm{DL}}$ obtained from the $\mathrm{CV}$ appears to be higher compared to the $C_{\mathrm{DL}}$ calculated from the EIS in the $\mathrm{H}_{2} / \mathrm{N}_{2}$ regime. (Figure $4 \mathrm{a}$ ). Higher $C_{\mathrm{DL}}$ measured in the $\mathrm{CV}$ can be related to the pseudocapacitance resulting from the fast electrosorption processes while cycling the electrode potential. For both methods $C_{\mathrm{DL}}$ increases with the anode loading due to the increase of the absolute catalyst mass and therefore the surface area.

The mass-specific capacitance $\left(c_{\mathrm{DL}}^{\mathrm{m}}\right)$ normalized to the amount of $\mathrm{IrO}_{2}$ in the active area shows little deviation between the anodes with different $\mathrm{IrO}_{2}$ loading, except for the samples with 0.05 and $0.16 \mathrm{mg}_{\mathrm{IrO} 2} \mathrm{~cm}^{-2}$ where it is approximately 2 times higher. Deviation from the constant $c_{\mathrm{DL}}^{\mathrm{m}}$ could be related to the inhomogeneous utilization of the catalyst in the case of thicker $\mathrm{CL}_{\mathrm{a}}$ with higher loading. A trend similar to the one of $C_{\mathrm{DL}}$ and $c_{\mathrm{DL}}^{\mathrm{m}}$ vs. the $\mathrm{IrO}_{2}$ loading is observed (cf. below) when estimating the mass-specific activity from the iR-free polarization curves. It is assumed that the $\mathrm{TiO}_{2}$ in the catalyst layer is an insulator and that the electronic conductivity of the catalyst is ensured through the $\mathrm{IrO}_{2}$ percolation network. ${ }^{35}$ The capacitances are normalized only to the mass of $\mathrm{IrO}_{2}$, since the contribution of $\mathrm{TiO}_{2}$ would in this case be negligible. At high $f$, the $45^{\circ}$ region appears in the Nyquist plot (Figure 3). Here, the impedance can be described by

$$
Z(f) \approx H F R+\sqrt{\frac{R_{\mathrm{CLa}}^{\mathrm{H}+}}{2 \pi f C_{\mathrm{DL}} j}}
$$

followed by the capacitive region at low frequencies, represented by the $90^{\circ}$ line in the Nyquist plot and the HFR-corrected impedance
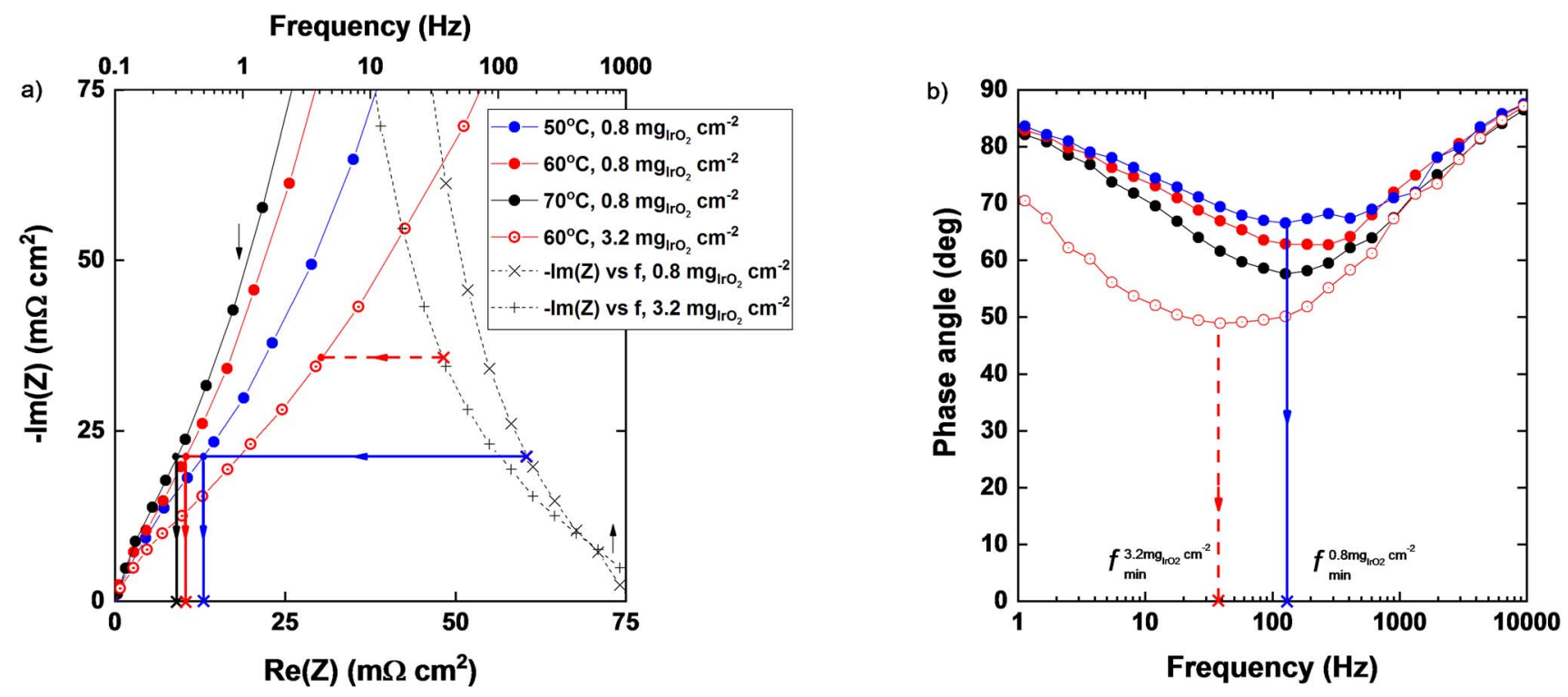

Figure 3. a) HFR-corrected impedance response of the PEWE cell with $0.8 \mathrm{mg}_{\mathrm{IrO}_{2}} \mathrm{~cm}^{-2}$ in the $\mathrm{H}_{2} / \mathrm{N}_{2}$ regime measured at 50,60 and $70^{\circ} \mathrm{C}$, showing the temperature dependence of $R_{\mathrm{CLa}}^{\mathrm{H}+}$. Impedance of the cell with $3.2 \mathrm{mg}_{\mathrm{IrO}_{2}} \mathrm{~cm}^{-2}$ is included to demonstrate the increase of $R_{\mathrm{CLa}}^{\mathrm{H}+}$ with the thickness of the anode catalyst layer. b) Bode phase plot of the cell with $0.8 \mathrm{mg}_{\mathrm{IrO}_{2}} \mathrm{~cm}^{-2}$ in the $\mathrm{H}_{2} / \mathrm{N}_{2}$ regime measured at 50,60 and $70^{\circ} \mathrm{C}$, and of the cell with $3.2 \mathrm{mg}_{\mathrm{IrO}} \mathrm{cm}^{-2}$ at $60^{\circ} \mathrm{C}$. The $R_{\mathrm{CLa}}^{\mathrm{H}+} / 3$ projection is obtained by first finding $f_{\min }$ at which $\varphi_{\min }$ appears in b), and extracting the impedance at $f_{\min }$ from the Nyquist plot in a). 


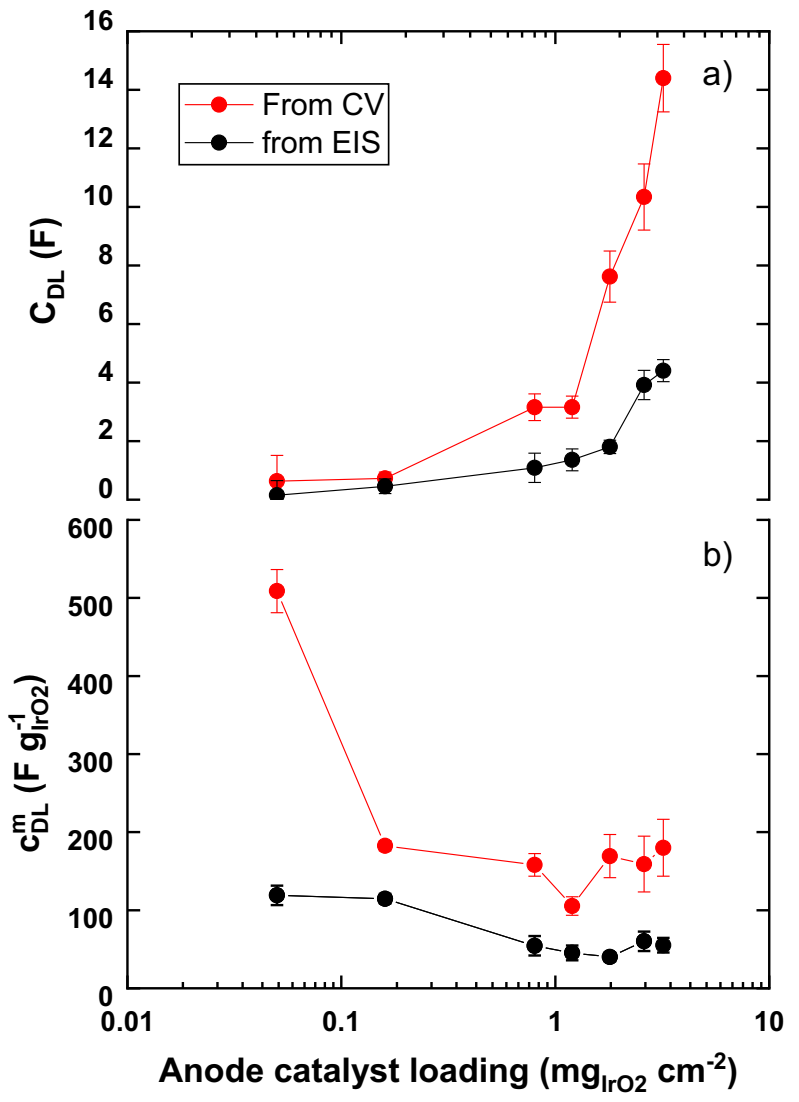

Figure 4. a) Double layer capacitance $C_{\mathrm{DL}}$ and b) mass-specific capacitance $c_{\mathrm{DL}}^{\mathrm{m}}$ of anode catalyst layers with different catalyst loading estimated from the cyclic voltammogram (red) and the impedance in the $\mathrm{H}_{2} / \mathrm{N}_{2}$ regime (black).

given by

$$
\underset{f \rightarrow 0}{Z(f)} \approx \frac{R_{\mathrm{CLa}}^{\mathrm{H}+}}{3}+\frac{1}{j C_{\mathrm{DL}} f}
$$

$R_{\mathrm{CLa}}^{\mathrm{H}+} / 3$ can be extracted from the Nyquist plots of $\mathrm{H}_{2} / \mathrm{N}_{2}$ operated cells by projecting the low $f$ impedance vertically to the real axis (Figure 3). ${ }^{22,32,33}$ An alternative approach is to determine $C_{D L}$ from Equation 3 and calculate $R_{\mathrm{CLa}}^{\mathrm{H}+} \cdot{ }^{24-26}$ Graphical extrapolation of $R_{\mathrm{CLa}}^{\mathrm{H}+}$ from the Nyquist plot relies on the presence of a vertical, capacitive impedance at low $f$, which is not always observed in the measured data. ${ }^{22,33,36}$ Deviations from the low $f$ capacitive behavior can be attributed to inhomogeneity of the catalyst layer, stemming from the preparation process or caused by the coarse PTL surface. ${ }^{32,37}$ The morphologic properties of the CL together with the CL/PTL interface properties might result in electrically insulated regions in the $\mathrm{CL}$ with high resistance, accessible only at low $f .{ }^{37}$ Furthermore, the wetting of the $\mathrm{CL}$ pores could be non-uniform in PEWE, ${ }^{11,33}$ resulting in distributed capacitance through the CL thickness. This can lead to a large variance in the extrapolation of the $R_{\mathrm{CLa}}^{\mathrm{H}+}$ (Figure 5). On the other hand, approximation of $C_{\mathrm{DL}}$ from Equation 3 requires that $-\operatorname{Im}(\mathrm{Z})$ plateaus at low $f .{ }^{24}$ If this is not the case, the uncertainty in the calculation of $C_{\mathrm{DL}}$, and subsequently of $R_{\mathrm{CLa}}^{\mathrm{H}+}$, increases. To circumvent the possible issues and errors in the estimation of $C_{\mathrm{DL}}$, we propose a method of finding the $C_{\mathrm{DL}}$ values at the frequency at which a minimum in the phase angle $\varphi$ is observed. This point marks the impedance transition from the $45^{\circ}$ region to the capacitive behavior. HFR-corrected impedance spectra in $\mathrm{H}_{2} / \mathrm{N}_{2}$ mode are used to calculate the $\varphi$ values (Figure 3 ), and the value of $f_{\varphi \min }$ is obtained at $\varphi_{\min }$. The method results in a defined kneepoint in the Nyquist plot based on the pore length, from which $R_{\mathrm{CLa}}^{\mathrm{H}+}$ and $C_{\mathrm{DL}}$ can be calculated. The $f_{\varphi \min }$ is lower for thicker catalyst layers since the current has to penetrate longer distances, which is evident in

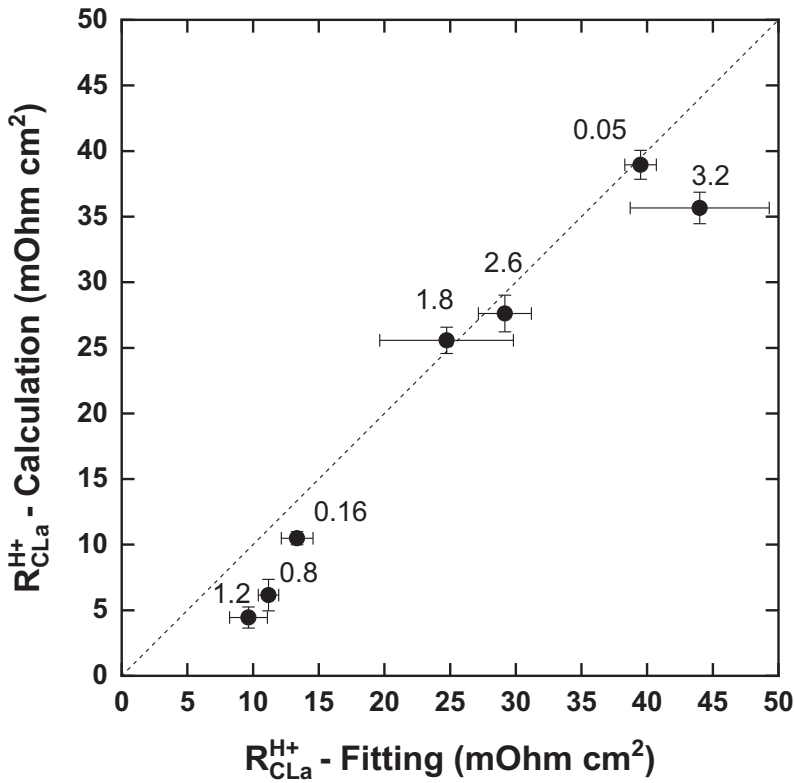

Figure 5. Comparison of $R_{\mathrm{CLa}}^{\mathrm{H}+}$ values calculated using the $f_{\varphi \min }$ approach (cf. Figure 3) and from the graphical extrapolation of the vertical line at low $f$. The minimum $R_{\mathrm{CLa}}^{\mathrm{H}+}$ is observed for the sample with an $\mathrm{IrO}_{2}$ loading in the range from 0.16 to $1.2 \mathrm{mg}_{\mathrm{IrO} 2} \mathrm{~cm}^{-2}$.

Figure 3 for samples of 3.2 vs. $0.8 \mathrm{mg}_{\mathrm{IrO} 2} \mathrm{~cm}^{-2}$. In this study we have used both methods and compared the $R_{\mathrm{CLa}}^{\mathrm{H}+}$ values obtained for PEWE

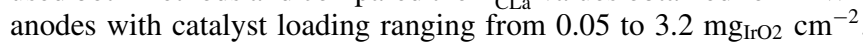
The values of $R_{\mathrm{CLa}}^{\mathrm{H}+}$ obtained from the graphical extrapolation from the Nyquist plot and from the $C_{\mathrm{DL}}$ at $f_{\varphi \min }$ are shown in Figure 5. Graphical extrapolation resulted in higher values of $R_{\mathrm{CLa}}^{\mathrm{H}+}$ in the case of very low and very high loadings, while both methods yield similar $R_{\mathrm{CLa}}^{\mathrm{H}+}$ for the cells with 1.8 and $2.6 \mathrm{mg}_{\mathrm{IrO} 2} \mathrm{~cm}^{-2}$.

The measured $R_{\mathrm{CLa}}^{\mathrm{H}+}$ decreases with higher cell temperatures due to the increased ionic conductivity of the ionomer in the $\mathrm{CL}_{\mathrm{a}}$ $\left(13.0 / 10.3 / 9.1 \mathrm{~m} \Omega \mathrm{cm}^{2}\right.$ at $50 / 60 / 70^{\circ} \mathrm{C}$ for $0.8 \mathrm{mg}_{\mathrm{IrO} 2} \mathrm{~cm}^{-2}$, respectively, based on data from Figure 3 ). The contribution of the ionic resistance of the $\mathrm{CL}_{\mathrm{a}}$ appears as a loss term of magnitude $R_{\mathrm{CLa}}^{\mathrm{H}+} / 3$ in the polarization curve, as part of mass transport losses $\left(\eta_{\mathrm{mtx}}\right)^{24,33,38}$ Improved proton transport in the $\mathrm{CL}_{\mathrm{a}}$ would partially account for the temperature dependent $\eta_{\text {mtx }}$ previously reported by Suermann et al. ${ }^{28}$ The change of $\eta_{\mathrm{mtx}}$ at $1 \mathrm{~A} \mathrm{~cm}^{-2}$ between 50 and $70^{\circ} \mathrm{C}$ was $\sim 7 \mathrm{mV}$ for the CL with $0.8 \mathrm{mg}_{\mathrm{IrO} 2} \mathrm{~cm}^{-2}$ in this study. The change in the area resistance of a $\sim 3 \mu \mathrm{m}$ thick Nafion ionomer sheet between 50 and $70^{\circ} \mathrm{C}$ is in the range of $\sim 1 \mathrm{~m} \Omega \mathrm{cm}^{2}$ (measured value in the $\mathrm{H}_{2} / \mathrm{N}_{2}$ regime $\sim 4 \mathrm{~m} \Omega \mathrm{cm}^{2}$ ), and can only account for a fraction of $\Delta \eta_{\mathrm{mtx}}$. Stronger sensitivity of $R_{\mathrm{CLa}}^{\mathrm{H}+}$ to temperature variations during $\mathrm{H}_{2} / \mathrm{N}_{2}$ measurements compared to what is reported for Nafion ${ }^{39}$ could stem from thin film limitations and the water distribution in the $\mathrm{CL}$ as a factor of the PTL/CL interface, and will be discussed further in the overpotential breakdown section below.

Considering $\mathrm{CL}_{\mathrm{a}}$ as a sheet electrode, $R_{\mathrm{CLa}}^{\mathrm{H}+}$ would decrease with the thickness, hence lower $\mathrm{IrO}_{2}$ loading. ${ }^{25}$ Two trends of $R_{\mathrm{CLa}}^{\mathrm{H}+}$ have been observed with varying loading in the $\mathrm{H}_{2} / \mathrm{N}_{2}$ regime. $R_{\mathrm{CL}}^{\mathrm{H}+}$ decreases with decreasing loading in the range from 3.2 to $1.2 \mathrm{mg}_{\mathrm{IrO} 2} \mathrm{~cm}^{-2}$ on the account of lower $\mathrm{CL}_{\mathrm{a}}$ thickness, since the proton transport path is longer for thicker catalyst layers. The lowest $R_{\mathrm{CLa}}^{\mathrm{H}+}$ values were observed for the $\mathrm{IrO}_{2}$ loading range from 1.2 to $0.16 \mathrm{mg}_{\mathrm{IrO} 2} \mathrm{~cm}^{-2}$. Interestingly, $R_{\mathrm{CLa}}^{\mathrm{H}+}$ was highest for the sample with $0.05 \mathrm{mg}_{\mathrm{IrO} 2} \mathrm{~cm}^{-2}$. Proton transport from the catalytically active sites relies both on throughplane as well as in-plane transport when the structure is composed of catalytic agglomerates connected by the ionomer. At very low $\mathrm{IrO}_{2}$ loading applied using the airbrush method the $\mathrm{CL}_{\mathrm{a}}$ structure becomes less homogeneous, as observed in the SEM images. This results in a 
lower degree of connectivity between the catalyst agglomerates by the ionomer network and subsequently higher in-plane resistance contribution to the $R_{\mathrm{CLa}}^{\mathrm{H}+}$. Alternative catalyst structures, such as the nanostructured thin film catalyst (NSTF) developed by $3 \mathrm{M},{ }^{21}$ and different application methods ${ }^{40}$ are necessary to achieve low-loaded anodes with uniform structure. The deviation of the measured impedance from the characteristic $45^{\circ}$ slope at high $f$ is more pronounced for the $\mathrm{CL}_{\mathrm{a}}$ with low $\mathrm{IrO}_{2}$ loading $\left(<1.2 \mathrm{mg}_{\mathrm{IrO} 2} \mathrm{~cm}^{-2}\right)$. This behavior of the impedance has previously been ascribed to electrodes with open, wedge-shaped pores, ${ }^{41,42}$ which is the case for low-loaded anodes with inhomogeneous distribution and packing of the catalyst agglomerates. Other possible causes of non-linear behavior of $R_{\mathrm{CLa}}^{\mathrm{H}+}$ with varying $\mathrm{IrO}_{2}$ loading are discussed in more detail in the section on overpotential analysis, in the context of the mass transport losses.

The average proton resistivity of the anode catalyst layers with $>0.05 \mathrm{mg}_{\mathrm{IrO} 2} \mathrm{~cm}^{-2}\left(\rho_{\mathrm{CLa}}^{\mathrm{H}+}\right)$ was found to be $130 \pm 33 \Omega \mathrm{cm}$, using the $R_{\mathrm{CLa}}^{\mathrm{H}+}$ and the $\mathrm{CL}_{\mathrm{a}}$ thickness $\left(d_{\mathrm{CLa}}\right)$ values from the SEM crosssectional images (Table I). The calculated value is in the range of values typically obtained for a fuel cell catalyst layer under fully humidified conditions at low ionomer to carbon ratio. ${ }^{26}$ The reason for a large variation in $\rho_{\mathrm{CLa}}^{\mathrm{H}+}$ in the case of $0.05 \mathrm{mg}_{\mathrm{IrO} 2} \mathrm{~cm}^{-2}$ is the strong deviation of the calculated $R_{\mathrm{CLa}}^{\mathrm{H}+}$ from the decreasing trend with the $\mathrm{IrO}_{2}$ loading. $\rho_{\mathrm{CLa}}^{\mathrm{H}+}$ is normally found to be a property of the catalyst layer that is independent of its thickness. ${ }^{26}$ Our $\mathrm{CL}_{\mathrm{a}}$ structure is laterally very inhomogeneous at lower loadings, and the corresponding in-plane $R_{\text {CLa }}^{\mathrm{H}+}$ contribution results in an increase of the apparent $\rho_{\mathrm{CLa}}^{\mathrm{H}+}$. Taking the ionomer resistivity $\left(\rho_{\mathrm{i}}^{\mathrm{H}+}\right)$ from the literature and using the ionomer volume fraction in the electrode $\left(\varepsilon_{\mathrm{i}}\right)$, the tortuosity $(\tau)$ can be calculated:

$$
\tau(\varepsilon)=\frac{\rho_{C L a}^{H+} \varepsilon_{i}}{\rho_{i}}
$$

We obtained $\varepsilon_{\mathrm{i}}=0.314$, following the equations given in detail by Liu et al., ${ }^{26}$ and assumed $\rho_{\mathrm{i}}^{\mathrm{H}+}$ from 8 to $11 \Omega \mathrm{cm}^{26,43}$ to find that $\tau$ goes through a minimum close to 1 for the cell with a loading of $1.2 \mathrm{mg}_{\text {IrO2 }} \mathrm{cm}^{-2}$ (Table I). The findings from the $\mathrm{H}_{2} / \mathrm{N}_{2}$ measurements suggest that the ionomer does not form a well-connected network between the catalytic agglomerates especially in the case of $0.05 \mathrm{mg}_{\mathrm{IrO} 2} \mathrm{~cm}^{-2}$, which is reflected in the $R_{\mathrm{CLa}}^{\mathrm{H}+}$ and the $\eta_{\mathrm{mtx}}$ values in the overpotential analysis.

Overpotential breakdown.-The overpotential breakdown of the PEWE polarization curve was conducted according to the procedure described in the Appendix. Polarization curves of PEWE cells with differently loaded $\mathrm{CL}_{\mathrm{a}}$ have been $i R$-corrected using the HFR to eliminate the influence of the variations in ohmic overpotential $\left(\eta_{\Omega}\right)$ that might stem from small variations in the cell assembly, membrane ionic resistance and contact resistances with different PTL samples. The HFR was found to be $257 \pm 16 \mathrm{mOhm} \mathrm{cm}^{2}$ for all samples at $60^{\circ} \mathrm{C}$, without any correlation to the $\mathrm{IrO}_{2}$ loading. Increasing the $\mathrm{CL}_{\mathrm{a}}$ loading results in lower $E_{i R-\text { free }}$ (Figure 6), which is lowest for the highest loading $\left(3.2 \mathrm{mg}_{\left.\mathrm{IrO} 2 \mathrm{~cm}^{-2}\right)}\right.$ and highest for the lowest loading $(0.05$ $\left.\mathrm{mg}_{\mathrm{IrO} 2} \mathrm{~cm}^{-2}\right)$, as may be expected. The $E_{i R-\text { free }}$ values of the cells with $0.16-3.2 \mathrm{mg}_{\mathrm{IrO} 2} \mathrm{~cm}^{-2}$ have a constant Tafel slope $b$ of $55 \pm 1$ $\mathrm{mV} / \mathrm{dec}$, and are offset by a factor depending on the $\mathrm{CL}_{\mathrm{a}}$ loading. The Tafel slope is higher only in the case of the $0.05 \mathrm{mg}_{\mathrm{IrO} 2} \mathrm{~cm}^{-2}$ sample with $70 \mathrm{mV} / \mathrm{dec}$. A similar effect of the $\mathrm{CL}_{\mathrm{a}}$ loading on the Tafel slope was observed by Bernt et al., ${ }^{11}$ albeit already at $0.2 \mathrm{mg}_{\mathrm{IrO} 2} \mathrm{~cm}^{-2}$. The catalyst activity $i_{\mathrm{a}}$, expressed as the current density at a fixed $E_{i R-\text { free }}$ of $1.47 \mathrm{~V}$, increased linearly with the $\mathrm{CL}_{\mathrm{a}}$ loading, as expected. The calculated mass activity $i_{\mathrm{a}}^{\mathrm{m}}$ is in the range of $10.2 \pm 1.3 \mathrm{~A} \mathrm{~g}^{-1}$ for the cells with $\mathrm{CL}_{\mathrm{a}}$ loading between 0.8 and $3.2 \mathrm{mg}_{\mathrm{IrO} 2} \mathrm{~cm}^{-2}$. However, the $i_{\mathrm{a}}^{\mathrm{m}}$ for the cell with $0.16 \mathrm{mg}_{\mathrm{IrO} 2} \mathrm{~cm}^{-2}$ is found to be approximately three times higher (Figure 7). Decreasing the loading even further to $0.05 \mathrm{mg}_{\mathrm{IrO} 2} \mathrm{~cm}^{-2}$ results in $i_{\mathrm{a}}^{\mathrm{m}}$ of $54.8 \pm 4.2 \mathrm{~A} \mathrm{~g}^{-1}$. The deviation of $i_{\mathrm{a}}^{\mathrm{m}}$ in the case of $\mathrm{CL}_{\mathrm{a}}$ with a very low $\mathrm{IrO}_{2}$ loading $\left(<0.2 \mathrm{mg}_{\mathrm{IrO} 2}\right.$ $\mathrm{cm}^{-2}$ ) indicates that the catalyst utilization of higher loaded CLs is low. ${ }^{44}$ Operando optical imaging studies of the $\mathrm{O}_{2}$ nucleation at the

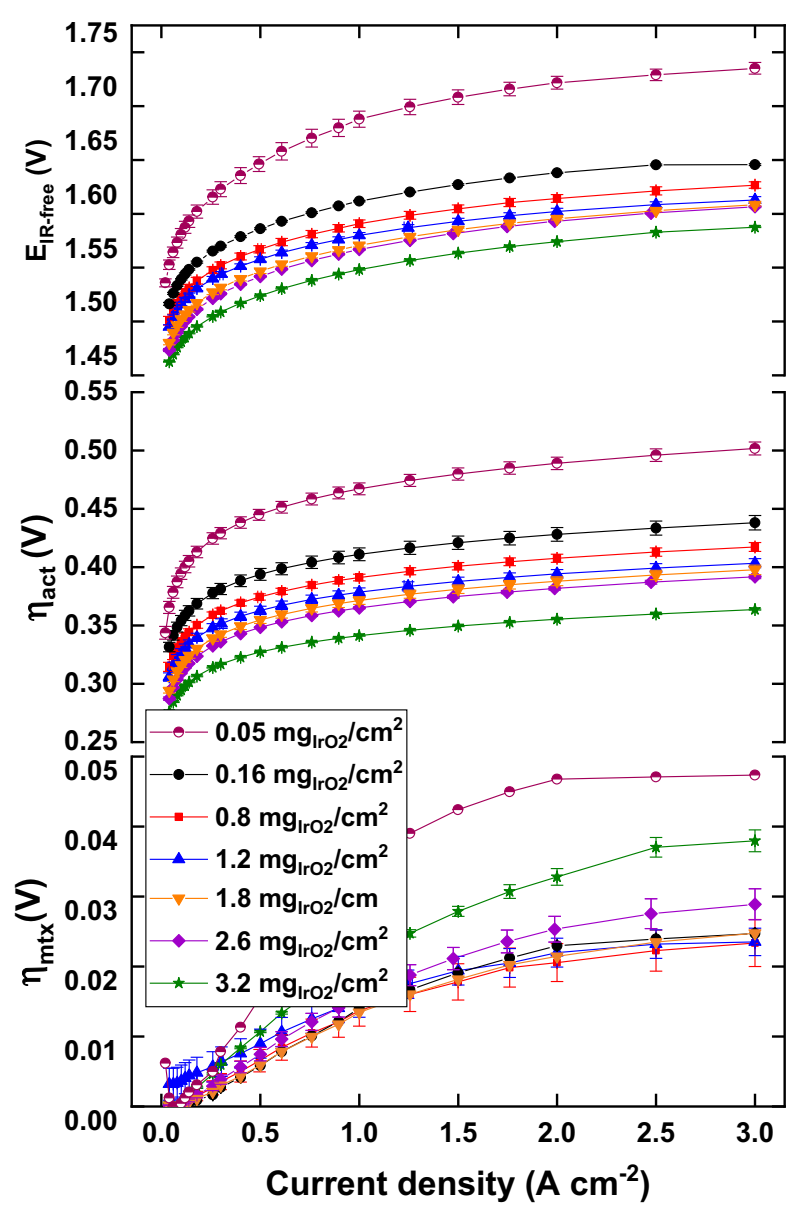

Figure 6. $E_{I R \text {-free }}, \eta_{\text {act }}$ and $\eta_{\mathrm{mtx}}$ for the cells with different $\mathrm{IrO}_{2}$ loadings. Data were obtained by $i R$-correcting the polarization curves using the HFR at $10 \mathrm{kHz}$ measured at $60^{\circ} \mathrm{C}$ and atmospheric pressure.

PTL/CL $L_{a}$ interface suggest that $\mathrm{O}_{2}$ evolution is localized at the $\mathrm{CL}_{\mathrm{a}}$ in direct contact with the PTL, while the catalyst in the PTL void (size: $50-500 \mu \mathrm{m}$ ) remained inactive. ${ }^{4-48}$ The limiting factor toward optimal catalyst utilization was the insufficient electronic conductivity of the catalyst layer. ${ }^{1,44-48}$ Assuming negligible differences in the in- and through-plane electronic conductivity of the $\mathrm{CL}_{\mathrm{a}}$, the catalyst material

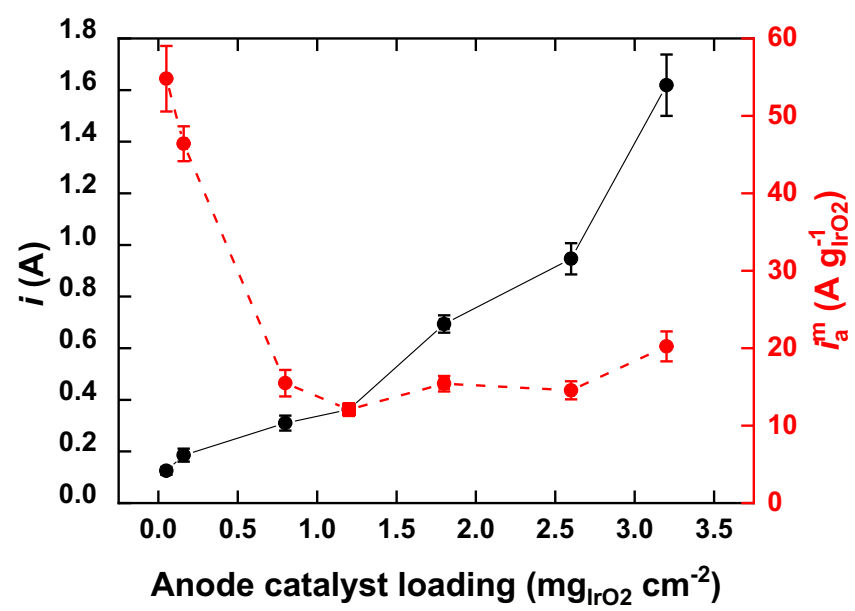

Figure 7. Activity in the form of the current measured at a fixed $i R$-free potential of $1.47 \mathrm{~V}$ (black), and the activity normalized to the $\mathrm{IrO}_{2}$ loading (mass activity, red). 


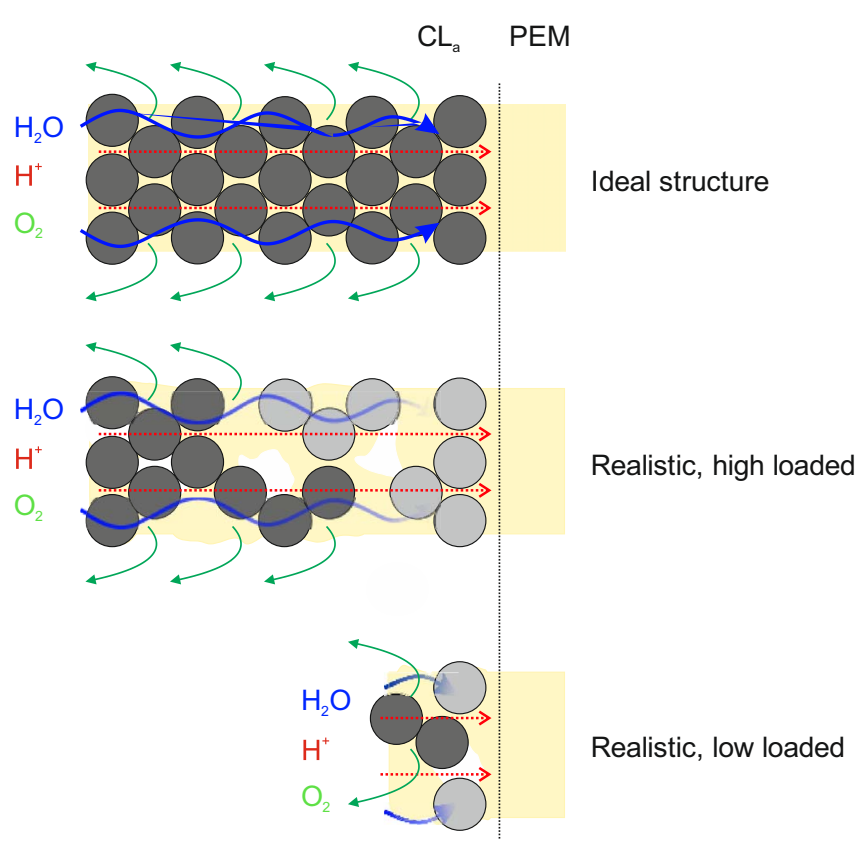

Figure 8. Schematic representation of the PEWE anode catalyst layer. The ionomer phase conducts protons from the catalytically active surface sites. The metallic phase provides the electronic conductivity of the layer.

closer to the PEM would not be fully utilized. Although more catalyst contributes to the OER in the case of anodes with higher $\mathrm{IrO}_{2}$ loading, the fraction of active material would be lower. This effect is illustrated in Figure 8.

The variation of the $\mathrm{IrO}_{2}$ loading affected $\eta_{\mathrm{mtx}}$ in a similar fashion as the $R_{\mathrm{CLa}}^{\mathrm{H}+}$ obtained in $\mathrm{H}_{2} / \mathrm{N}_{2}$ configuration, i.e. in the absence of faradaic current (Figure 9). Since the $R_{\mathrm{CLa}}^{\mathrm{H}+}$ contribution appears as a part of the $\eta_{\mathrm{mtx}},{ }^{33,38}$ a good correlation in the trend of these two independently determined quantities can be taken as a validation of the transmission line model method to determine $R_{\mathrm{CLa}}^{\mathrm{H}+}$ in PEWE cells. Structural inhomogeneity of low $\mathrm{IrO}_{2}$-loaded $\mathrm{CL}_{\mathrm{a}}$ related to the preparation method could be the cause of the non-linear behavior of $R_{\mathrm{CLa}}^{\mathrm{H}+}$, and consequently $\eta_{\mathrm{mtx}}$. Low $\mathrm{IrO}_{2}$ loadings were found to have a similar effect on the electronic conductivity of the catalyst layer. ${ }^{11}$ It is important to note that $R_{\mathrm{CLa}}^{\mathrm{H}+}$ is very sensitive to variations in the water content of the ionomer in the $\mathrm{CL}_{\mathrm{a}} \cdot{ }^{22,24-26}$ Bernt et al. ${ }^{11}$ have suggested that the water distribution might be different for thick and thin $\mathrm{CL}_{\mathrm{a}}$,

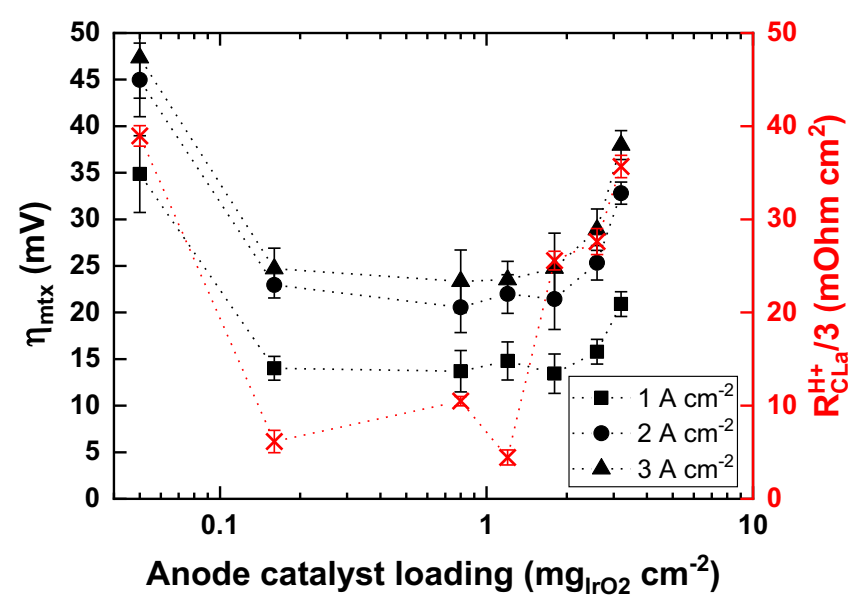

Figure 9. $R_{\mathrm{CLa}}^{\mathrm{H}+} / 3$ (red) and $\eta_{\mathrm{mtx}}\left(\right.$ black) at $1(\boldsymbol{\square}), 2(\bullet)$ and $3(\boldsymbol{\Delta}) \mathrm{A} \mathrm{cm}^{-2}$ for anode catalyst layers with different $\mathrm{IrO}_{2}$ loading, $60^{\circ} \mathrm{C}$. which would affect $R_{\mathrm{CLa}}^{\mathrm{H}+}$, and ultimately $\eta_{\mathrm{mtx}}$. As the OER in PEWE cells occurs below the PTL particles, ${ }^{45-48}$ the water has to diffuse both laterally and perpendicularly to the membrane surface (Figure 8) from the PTL pore to the active sites below the PTL particle. ${ }^{33}$ Since the water diffusion through Nafion thin films $(<60 \mathrm{~nm})$ is orders of magnitude slower compared to the bulk, ${ }^{49,50}$ thicker CLs would result in longer diffusion distances for the reactant, and thus yield an inhomogeneous water distribution in the CL. Development of an anodic PTL with a microporous layer is necessary to alleviate problems which diminish the electronic and ionic connectivity of anode CLs with low $\mathrm{IrO}_{2}$ loadings. ${ }^{11}$

\section{Conclusions}

Understanding the relationship between cell performance and the structural features of the anode catalyst layer in PEWE is necessary for tailoring next-generation catalyst layers for optimal transport properties and activity. We provide a methodology to determine the proton transport resistance in the anode catalyst layer, $R_{\mathrm{CLa}}^{\mathrm{H}+}$, based on impedance measurements in the $\mathrm{H}_{2} / \mathrm{N}_{2}$ regime by identifying the knee point in the Nyquist plot corresponding to the minimum phase angle observed in the Bode phase plot. The presented diagnostic method is a universal tool for characterizing catalyst layers for water electrolyzers. Application of the method to anodes with varying $\mathrm{IrO}_{2}$ loading from 0.05 to $3.2 \mathrm{mg}_{\mathrm{IrO} 2} \mathrm{~cm}^{-2}$ has revealed that the loading affects $R_{\mathrm{CLa}}^{\mathrm{H}+}$ in a non-linear fashion. Overpotential analysis showed that there is a correlation between the trends observed in $R_{\mathrm{CLa}}^{\mathrm{H}+}$ and the mass transport overpotential $\eta_{\mathrm{mtx}}$ versus the $\mathrm{IrO}_{2}$ loading. Low loaded anodes $\left(<1.2 \mathrm{mg}_{\mathrm{IrO} 2} \mathrm{~cm}^{-2}\right)$ exhibit a high degree of in-plane inhomogeneity, which could explain the non-linear relation between the $\mathrm{IrO}_{2}$ loading and $R_{\mathrm{CLa}}^{\mathrm{H}+}$. Other potential causes related to the water management in the catalyst layer are discussed in the context of $\eta_{\mathrm{mtx}}$ values measured with different $\mathrm{IrO}_{2}$ loadings.

We have demonstrated that more $\mathrm{IrO}_{2}$ catalyst yields lower activation losses, as expected, yet a lower effective utilization of the material. Moreover, a systematic variation of the $\mathrm{IrO}_{2}$ loading has revealed a relationship between the activation overpotential $\eta_{\text {act }}$ and $\eta_{\mathrm{mtx}}$ that can to a certain extent compensate the apparent loss of voltage efficiency in going toward lower $\mathrm{IrO}_{2}$ loading. Optimizing the morphology of the catalyst layer by adapting the preparation method could open a pathway to low loaded catalyst layers with high volumetric utilization of the active material.

\section{Acknowledgments}

Funding by the Swiss Federal Office of Energy (grant-no. 50119801 ) is gratefully acknowledged. TJS thanks Innosuisse and the Swiss Competence Center for Energy Research Heat \& Electricity Storage. We acknowledge Katrine Elsoe (DTU) for performing preliminary series of catalyst layer coating trials in the framework of a research stay at PSI.

\section{Appendix}

Overpotential analysis. - The electrolyzer cell voltage $\left(E_{\text {cell }}\right)$ is composed of the reversible cell voltage $\left(E_{\text {rev }}\right)$, ohmic $\left(\eta_{\Omega}\right)$, kinetic $\left(\eta_{\text {act }}\right)$, and mass-transport $\left(\eta_{\text {mtx }}\right)$ overpotentials (Equation A1). ${ }^{27-29,33}$

$$
E_{\text {cell }}=E_{\text {rev }}+\eta_{a c t}+\eta_{\Omega}+\eta_{m t x}=E_{\text {rev }}+\eta_{a c t}+i \cdot\left(R_{P E M}+R_{e l}\right)+i \cdot R_{C L a}^{H+}+\eta_{m t x-r e s t}
$$

$E_{\mathrm{rev}}$ is given by the Nernst equation for the operating pressure, temperature and the activity of the species involved in the reaction (Equation A2). We assume unity for the activity of water and ideal gas behavior for the gases. For the temperatures used in this study, $50^{\circ} \mathrm{C}$, $60 \mathrm{C}, 70^{\circ} \mathrm{C}, E_{\mathrm{rev}}$ is $1.195 \mathrm{~V}, 1.186 \mathrm{~V}, 1.177 \mathrm{~V}$, respectively.

$$
E_{r e v}(p, T)=E_{r e v}^{0}(T)+\frac{R \cdot T}{2 \cdot F} \ln \left(\frac{a\left(H_{2}\right) \cdot \sqrt{a\left(O_{2}\right)}}{a\left(H_{2} O\right)}\right)
$$

$\eta_{\mathrm{ohm}}$ is the result of losses related to the membrane proton transport processes $\left(R_{\mathrm{PEM}}\right)$ and the contact resistances $\left(R_{\mathrm{el}}\right)$ and follows Ohm's law, $\left.\eta_{\Omega}=i \cdot\left(R_{\mathrm{PEM}}+R_{\mathrm{el}}\right)\right)^{7,51}$ These losses are obtained when correcting the polarization curve with the high-frequency resistance (HFR), in this case measured at $10 \mathrm{kHz}$. $\eta_{\text {act }}$ is related to sustaining the sluggish anodic 
oxygen evolution reaction (OER). ${ }^{52}$ The cathode reaction is assumed not to be kinetically limiting. ${ }^{38} \eta_{\text {act }}$ is obtained by subtracting $E_{\text {rev }}$ from the Tafel line, which is calculated from the $i R$-free cell voltage $\left(E_{i R \text {-free }}\right)$ at low current densities $\left(0.01-0.1 \mathrm{~A} \mathrm{~cm}^{-2}\right)$. $\eta_{\mathrm{mtx}}$ appears at higher current densities and is obtained from the difference of $E_{i R-\text { free }}$ and the fitted Tafel line. Part of $\eta_{\mathrm{mtx}}$ is related to the proton transport resistance in the $\mathrm{CL}_{\mathrm{a}},{ }^{11,33,38}$ and can be obtained from the Nyquist plot of the EIS during $\mathrm{H}_{2} / \mathrm{N}_{2}$ operation. ${ }^{33}$

\section{ORCID}

Ugljesa Babic (1) https://orcid.org/0000-0002-6774-1001 Alexandra Pătru (10 https://orcid.org/0000-0002-6555-590X Thomas J. Schmidt (D) https://orcid.org/0000-0002-1636-367X Lorenz Gubler (D) https://orcid.org/0000-0002-8338-6994

\section{References}

1. R. Winkler-Goldstein and A. Rastetter, Green, 3, 69 (2013).

2. F. N. Büchi, M. Hofer, C. Peter, U. D. Cabalzar, J. Bernard, U. Hannesen, T. J. Schmidt, A. Closset, and P. Dietrich, RSC Advances, 4, 56139 (2014).

3. B. Bensmann, R. Hanke-Rauschenbach, G. Müller-Syring, M. Henel, and K. Sundmacher, Applied Energy, 167, 107 (2016).

4. M. Sterner and I. Stadler, in Energiespeicher - Bedarf, Technologien, Integration, Springer Vieweg, (2014).

5. A. Buttler and H. Spliethoff, Renewable and Sustainable Energy Reviews, 82, 2440 (2018).

6. T. J. Schildhauer and S. M. A. Biollaz, CHIMIA International Journal for Chemistry, 69, 603 (2015)

7. M. Carmo, D. L. Fritz, J. Mergel, and D. Stolten, International Journal of Hydrogen Energy, 38, 4901 (2013)

8. U. Babic, M. Suermann, F. N. Büchi, L. Gubler, and T. J. Schmidt, Journal of The Electrochemical Society, 164, F387 (2017).

9. L. Bertuccioli, A. Chan, D. Hart, F. Lehner, B. Madden, and E. Standen, Study on Development of Water Electrolysis in the EU by E4tech Sàrl with Element Energy Ltd for the Fuel Cells and Hydrogen Joint Undertaking (2014).

10. DOE Technical Targets for Hydrogen Production from Electrolysis, Office of Energy Efficiency \& Renewable Energy, accessed on 11.07.2018, retrieved from http://energy. gov/eere/fuelcells/doe-technical-targets-hydrogen-production-electrolysis , (2015)

11. M. Bernt, A. Siebel, and H. Gasteiger, Journal of the Electrochemical Society, $\mathbf{1 6 5}$, F305 (2018).

12. P. Millet, N. Mbemba, S. A. Grigoriev, V. N. Fateev, A. Aukauloo, and C. Etiévant, International Journal of Hydrogen Energy, 36, 4134 (2011).

13. O. Kasian, S. Geiger, P. Stock, G. Polymeros, B. Breitbach, A. Savan, A. Ludwig, S. Cherevko, and K. J. J. Mayrhofer, Journal of The Electrochemical Society, 163, F3099 (2016).

14. Umicore, Precious Materials Handbook | A specialised Book about the contribution of metal-based materials to crucial applications in line with specific megatrends, Umicore AG \& Co. KG, Hanau-Wolfgang, Germany (2012).

15. H. Xu, B. Rasimick, M. Riera-Smith, B. Pivovar, S. Alia, K. C. Neyerlin, K. Lewinski, and S. Luopa, High-Performance, Long-Lifetime Catalysts for Proton Exchange Membrane Electrolysis, DOE Hydrogen and Fuel Cells Program, Annual Progress Report, (2015).

16. H.-S. Oh, H. N. Nong, T. Reier, M. Gliech, and P. Strasser, Chem. Sci, 6, 3321 (2015).

17. L. C. Seitz, C. F. Dickens, K. Nishio, Y. Hikita, J. Montoya, A. Doyle, C. Kirk, A. Vojvodic, H. Y. Hwang, J. K. Norskov, and T. F. Jaramillo, Science, 353, 1011 (2016).

18. D. F. Abbott, D. Lebedev, K. Waltar, M. Povia, M. Nachtegaal, E. Fabbri, C. Copéret, and T. J. Schmidt, Chemistry of Materials, 28, 6591 (2016).
19. E. Oakton, D. Lebedev, M. Povia, D. F. Abbott, E. Fabbri, A. Fedorov, M. Nachtegaal, C. Copéret, and T. J. Schmidt, ACS Catalysis, 7, 2346 (2017).

20. D. Lebedev, M. Povia, K. Waltar, P. M. Abdala, I. E. Castelli, E. Fabbri, M. V. Blanco, A. Fedorov, C. Copéret, N. Marzari, and T. J. Schmidt, Chemistry of Materials, 29, 5182 (2017)

21. K. A. Lewinski, D. F. v. d. Vliet, and S. M. Luopa, ECS Transactions, 69, 893 (2015).

22. S. S. Kocha, in Handbook of Fuel Cells, W. Vielstich, A. Lamm, H. Gasteiger, and H. Yokokawa Editors, p. 538, John Wiley \& Sons, (2010).

23. B. E. Conway, in Electrochemical Supercapacitors, p 382, Springer, (1999).

24. Y. Liu, M. W. Murphy, D. R. Baker, W. Gu, C. Ji, J. Jorne, and H. A. Gasteiger, Journal of The Electrochemical Society, 156, B970 (2009).

25. W. Gu, D. R. Baker, Y. Liu, and H. A. Gasteiger, in Handbook of Fuel Cells, W. Vielstich, A. Lamm, H. A. Gasteiger, and H. Yokokawa Editors, John Wiley \& Sons, Ltd, (2010).

26. Y. Liu, C. Ji, W. Gu, D. R. Baker, J. Jorne, and H. A. Gasteiger, Journal of The Electrochemical Society, 157, B1154 (2010).

27. M. Suermann, T. J. Schmidt, and F. N. Büchi, Electrochimica Acta, 211, 989 (2016).

28. M. Suermann, K. Takanohashi, A. Lamibrac, T. J. Schmidt, and F. N. Büchi, Journal of The Electrochemical Society, 164, F973 (2017).

29. H. Ito, T. Maeda, A. Nakano, A. Kato, and T. Yoshida, Electrochimica Acta, 100, 242 (2013).

30. T. J. Schmidt and J. Baurmeister, Journal of Power Sources, 176, 428 (2008).

31. H. A. Gasteiger, S. S. Kocha, B. Sompalli, and F. T. Wagner, Applied Catalysis B: Environmental, 56, 9 (2005).

32. M. C. Lefebvre, R. B. Martin, and P. G. Pickup, Electrochemical and Solid-State Letters, 2, 259 (1999).

33. U. Babic, T. J. Schmidt, and L. Gubler, Journal of The Electrochemical Society, $\mathbf{1 6 5}$, J3016 (2018).

34. R. Makharia, M. F. Mathias, and D. R. Baker, Journal of The Electrochemical Society, 152, A970 (2005)

35. E. Oakton, D. Lebedev, A. Fedorov, F. Krumeich, J. Tillier, O. Sereda, T. J. Schmidt, and C. Coperet, New Journal of Chemistry, 40, 1834 (2016).

36. D. Malevich, B. R. Jayasankar, E. Halliop, J. G. Pharoah, B. A. Peppley, and K. Karan, Journal of The Electrochemical Society, 159, F888 (2012).

37. M. C. Lefebvre, R. B. Martin, and P. G. Pickup, Electrochemical and Solid-State Letters, 2, 259 (1999).

38. M. Bernt and H. A. Gasteiger, Journal of The Electrochemical Society, 163, F3179 (2016).

39. B. R. Matos, C. A. Goulart, E. I. Santiago, R. Muccillo, and F. C. Fonseca, Applied Physics Letters, 104, 091904, (2014).

40. K. E. Ayers, J. N. Renner, N. Danilovic, J. X. Wang, Y. Zhang, R. Maric, and H. Yu, Catalysis Today, 262, 121 (2016).

41. D. Cericola and M. E. Spahr, Electrochimica Acta, 191, 558 (2016).

42. H. Keiser, K. D. Beccu, and M. A. Gutjahr, Electrochimica Acta, 21, 539 (1976)

43. S. M. Slade, T. R. Ralph, C. P. d. León, S. A. Campbell, and F. C. Walsh, Fuel Cells, 10, 567 (2010).

44. C. Rozain, E. Mayousse, N. Guillet, and P. Millet, Applied Catalysis B: Environmental, 182, 153 (2016)

45. J. Mo, Z. Kang, S. T. Retterer, D. A. Cullen, T. J. Toops, J. B. Green, M. M. Mench, and F.-Y. Zhang, Science Advances, 2, e1600690 (2016).

46. Z. Kang, J. Mo, G. Yang, S. T. Retterer, D. A. Cullen, T. J. Toops, J. B. Green Jr, M. M. Mench, and F.-Y. Zhang, Energy Environ. Sci., 10, 166 (2017).

47. Z. Kang, G. Yang, J. Mo, S. Yu, D. A. Cullen, S. T. Retterer, T. J. Toops, M. P. Brady, G. Bender, B. S. Pivovar, J. B. Green, and F.-Y. Zhang, International Journal of Hydrogen Energy, 43, 14618 (2018).

48. Z. Kang, G. Yang, J. Mo, Y. Li, S. Yu, D. A. Cullen, S. T. Retterer, T. J. Toops, G. Bender, B. S. Pivovar, J. B. Green, and F.-Y. Zhang, Nano Energy, 47, 434 (2018).

49. E. M. Davis, C. M. Stafford, and K. A. Page, ACS Macro Letters, 3, 1029 (2014).

50. S. A. Eastman, S. Kim, K. A. Page, B. W. Rowe, S. Kang, C. L. Soles, and K. G. Yager, Macromolecules, 45, 7920 (2012)

51. C. Rakousky, U. Reimer, K. Wippermann, M. Carmo, W. Lueke, and D. Stolten, Journal of Power Sources, 326, 120 (2016).

52. E. Fabbri, A. Habereder, K. Waltar, R. Kötz, and T. J. Schmidt, Catal. Sci. Technol., 4, 3800 (2014). 